\title{
Allelopathic Effects of Some Selected Tree Species on the Germination and Growth of Cowpea (Vigna unguículata L. Walp.)
}

\author{
M. O. Aleem', L. O. Alamu ${ }^{2 *}$, O. S. Olabode ${ }^{1}$ \\ ${ }^{1}$ Department of Crop Production and Soil Science, Ladoke Akintola University of Technology, Ogbomoso, \\ Nigeria \\ ${ }^{2}$ Department of Crop and Environmental Protection, Ladoke Akintola University of Technology, Ogbomoso, \\ Nigeria \\ Email: ${ }^{*}$ fowoltfaith@hotmail.com
}

Received 10 April 2014; revised 18 May 2014; accepted 10 June 2014

Copyright $@ 2014$ by authors and Scientific Research Publishing Inc.

This work is licensed under the Creative Commons Attribution International License (CC BY).

http://creativecommons.org/licenses/by/4.0/

(c) (i) Open Access

\section{Abstract}

The allelopathic effect of three tree species (Azardiracta indica, Vitellaria paradoxa, and Parkia biglobosa) on germination and growth of cowpea was investigated in the Southern Guinea Savannah agro ecological zone of Nigeria. The experiment was laid out in Randomized Complete Block Design (RCBD) with three (3) replicates. Data were collected on germination, plant height, stem diameter, number of leaves, number of branches, root length, the above grand biomass and the below grand biomass and were subjected to statistical analysis using Analysis of Variance (ANOVA) while the significant mean was separated using Duncan's Multiple Range Test (DMRT) at $5 \%$ possibility level. Results showed that the tree species brought about considerable inhibition in the germination of cowpea seeds and in its growth parameters. The statistical germination value of the cowpea seeds under the tree species had decreased value thus indicating that growth inhibitions were seriously felt. It was apparent that Parkia biglobosa (53.33) and Vitellaria paradoxa (60.00) had more inhibitory effect on cowpea seeds germinability than that of Azardiracta indica. (63.33) while all the treatments are lower than that of control (100). The tree species had similar inhibition capability in the cowpea plant height, stem circumference, number of leaves, above grand biomass and below grand biomass. However, in all treatment, statistic showed that there is no significant difference $(p<0.05)$ among the means.

\section{Keywords}

\section{Allelopathy, Inhibition, Azardiracta indica, Vitellaria paradoxa, Parkia biglobosa}

\footnotetext{
*Corresponding author.

How to cite this paper: Aleem, M. O., Alamu, L. O., \& Olabode, O. S. (2014). Allelopathic Effects of Some Selected Tree Species on the Germination and Growth of Cowpea (Vigna unguiculata L. Walp.). Open Journal of Forestry, 4, 310-315. 


\section{Introduction}

Allelopathy has been defined as an adverse influence or interference of one plant or microorganism on another (Rice, 1984). Interference refers, therefore, to the overall effect of one plant upon another and encompasses both allelopathy and competition. Competition involves the removal or diminution of a shared resource, while allelopathy involves the addition of a chemical compound, which negatively affects other neighboring plants, in the environment through different processes (Rice, 1984; Putnam, 1985). In agricultural practice, allelopathy is exploited for weed control (Kohli et al., 1998). Association and dissociation pattern between certain plant species are widely known. Such phenomenon may be governed by direct competition for necessary growth factors or through addition of allelopathic chemicals into the soil environment (Einhelling, 1996; Ashrafi et al., 2007). It has been documented that allelopathy may play an important role in plant-plant interference by those chemical compounds (Inderjit \& Dakshini, 1992). Some of those compounds are released into the environment through leaching, litter decomposition, root exudation or direct volatilization, and could affect (either positively or negatively) germination and growth of other species (Gross \& Parthier, 1994; Seligler, 1996). A number of weed and crop species have been reported to possess allelopathic effects on the growth of other plant species (Rice, 1984). Chemicals with inhibitory activity are present in many plants and in many organs, including leaves, flowers, fruits and buds (Inderjit, 1996; Ashrafi et al., 2007).

Azadiracta indica, or Neem Tree, is an evergreen tree native to Southeast Asia. All parts of the tree have been used medicinally for centuries. It is widely used in toothpastes, soaps and lotion today, as well as biological insecticide. Neem (Azadiracta indica, A. Juss) is a versatile tree native to South and Southeast Asia, Japan, tropical USA, South America, Australia and Africa (Bokhari \& Aslam, 1985; Von Maydell, 1986). Butyrospermum parkii is a member of the Sapotaceae family, and is divided into two subspecies: nilotica and paradoxa. The ranges of the two are mutually exclusive, although they have been found within $175 \mathrm{~km}$ of one another (Hall et al., 1996). The difference between the two subspecies occurs primarily in the consistency of the fat content found within its nut (Boffa, 1999). Butyrospermum parkii is also referred to as Vitellaria paradoxa Gaertn.f (Booth \& Wickens, 1988; Von Maydell, 1990; Hall et al., 1996). In French it is called Karité or arbre a beurre (butter tree) and in English "the Shea Butter Tree". Vitellaria is a deciduous tree of medium size, with a spherical crown. It often reaches heights of 10 - 15 meters, with rare recorded occasions of up to 25 meters (Von Maydell, 1990). Vitellaria is a light demanding, slow growing tree, with a thick and fissured bark. Shea nut "butter" has many uses and may or may not be refined. Shea butter is mostly used for cosmetics. Throughout Africa, it is used extensively for food and medicinal purposes, and is a major source of dietary fat (Maranz et al., 2004). Locust Beans belong to the Familiy Fabaceae-Mimosoideae, and Synonyms to Minosa biglobosa Jacq. Parkia biglobosa is native to Africa and is an important multipurpose tree of West African savannah land, and one of the most common species of the pack land agroforestry system (ICRAF, 2011). It is prominent in strongly seasonal climates where the dry season lasts 4 to 8 months. It regenerates well in nature but the wildings are often damaged by bush fires (Hopkins, 1983). The seeds of Parkia are used in preparation of dawadawa, a protein and fat rich food (Mertz et al., 2001). The dried powder is often mixed with water to produce a drink called dozim by the Dagbani tribe and bololo in Hausa (Hall et al., 1997). However, very few reports or literatures available concerning the allelopathic potential of tropical and subtropical plants like Neem (Azadiracta indica) have been published.

Cowpea (Vigna unguiculata L. Walp.), is an annual legume. It is also commonly referred to southern pea, black eye pea, crowther pea, lubia, niebe, coupe or frijole. Cowpea originated in Africa and is widely grown in Africa, Latiin America, Southeast Asia and in the Southern United States. It is chiefly used as a grain crop, for animal fodder, or as a vegetable. The history of cowpea dates to ancient West African cereal farming, 5 to 6 thousand years ago, where it was closely associates with the cultivation of sorghum and pearl millet (Davis et al., 1991). Cowpea seed is a nutritious component in the human diet, as well as a nutritious livestock feed. This experiment was set up to investigate the possibility of using the trees under which the agronomy crops were planted as on-farm agroforestry plants. The use of such trees will enhance green agriculture to mitigate against climate change.

\section{Methodology}

The experiment was carried out at the Teaching and Research Farms of Ladoke Akintola University of Techno- 
logy, Ogbomoso, Oyo State, Nigeria, which falls within the guinea savannah agro-ecological zone of Nigeria. Ogbomoso lies between Longitude $4^{\circ} 10^{\prime} \mathrm{E}$ and Latitude $8^{\circ} 10^{\prime} \mathrm{N}$. This location is found to be cold and dry from November to March and then warm and moist from April to October. It is characterized by bimodal rainfall distribution whereby the early rainy season starts in late March and ends in late July/early August, followed by a short dry spell in August and finally the late rainy season from August to November. The annual mean rainfall is between $1150 \mathrm{~mm}$ and 1250 (Olaniyi et al., 2006).

Cowpea variety (82E9) was obtained from International Institute of Tropical Agriculture (IITA) Ibadan. Three (3) tree species; neem, (Azardirachta indica), locust bean (Parkia biglobosa) and shear butter (Vitellaria paradoxa) used were found as volunteers plants. Three beds each $3 \mathrm{~m}$ by $3 \mathrm{~m}$ dimension were prepared at a spacing of $90 \mathrm{~cm} \times 30 \mathrm{~cm}$ under each of the trees respectively. Weeding was manually done using hoe as at 2, 4, 6 , and 8 weeks after sowing. There were three replicates thus making a total of twenty seven (27) beds. Seeds cowpea was planted on each of the beds. The treatment combinations were replicated four (4) times and the trial was laid out in a Randomized Complete Block Design (RCBD). Control experiment was also set up along the treatments outside the canopy of the trees which were also replicated in three times. For the pot experiment, two seeds of maize, cowpea and sesame were planted in the $5 \mathrm{~kg}$ of soil collected from under the canopy of Azardiracta indica, Parkia biglobosa and Vitellaria paradoxa. Another soil from open space was included as control for the planting of the studied arable crops. The control was laid out in a completely randomized design (RCD). Data were collected on seedling emergence at 4, 6, 8, and 10 days after sowing (DAS) and later converted to percentage emergence. Seedling growth parameters measured included plant height using measuring tape, stem girth with venier calipers which first gave the value of the diameter, which was later converted to circumference using a fomular of $\pi$ D (i.e. 3.142) multiplied by the obtained diameter (D) value, number of branches determined by direct counting of all well-developed branches per plant and number of leaves. These were measured at 2, 4, 6, 8 and 10 weeks after sowing (WAS). Seedlings root lengths were measured at harvest using measuring tape. The results obtained from the plants under these tree species were compared statistically to those obtained from the control experiments following the procedure of analysis of variance (ANOVA) where differences were observed, Duncan's Multiple Range Test (DMRT), at 5\% level of probability, was used to compare differences among the treatment means.

\section{Results}

Allelopathy had been reported on a wide range of plant species. It however appears to be best developed in perennial and woody species of arid environment and early successional species of more humid regions. In addition, incorporation of trees into the farm lands is well recognized under agro-forestry systems for maintaining soil fertility and crop productivity (Singh et al., 1997). Results of the present study showed that the tested tropical tree species inhibited the germination of the cowpea seeds. Statistically, there was no significant difference among the means. According to Rice (1984), plants are known to exhibit allelopathy by releasing water soluble phyto-toxins from leaves, stem, roots fruits and seeds and such metabolites play an inhibitory role in delay or complete inhibition of seed germination. This resulted into stunted growth and injury to root systems of plants.

Cowpea germination both on the field and in the pot experiment were significantly affected by the tree species. Faster germination was observed in the control than the treated plots across the number of days the experiment was monitored. Statistically however, there were no significant $(p<0.05)$ difference in both the rate and total germination of cowpea treated with tree species in the two experiments (Table 1). In cowpea, the control treatments were better than the treated plots except in number of leaves. However, with the detrimental effects of the tree species on cowpea number of branches, the effect is likely to be very pronounced in cowpea grain yield. Shaukat and Siddiqui (2001) had attributed reduction or outright stoppage of growth to inhibitory substances, in the soil which in this case is suspected to have been deposited by the tree species.

The control treatment was superior to the treated plants in the plant height, stem diameter and numbers of branches in the two experiments (Tables 2-5) in the two experiments. Cowpea response to the treatments was similar over the period of monitoring in the two experiments except at 2 WAS in the pot and 2 WAS and 4 WAS in the field experiment where Neem was superior to other treatments with respect to plant height (Table 3 and Table 4), but affected cowpea number of leaves (Table 5) at 4 WAS and 6 WAS in the field experiment than others. Locust was less detrimental to cowpea number of branches at both experiments. The tree species visually vegtatively affected cowpea plant height, stem diameter, number of leaves and root length on both the field and pot experiments. 
Table 1. Effect of allelopathy of selected agroforestry trees on cowpea germination.

\begin{tabular}{ccccccccc}
\hline & \multicolumn{3}{c}{ POT Percentage germination } & \multicolumn{3}{c}{ FIELD Percentage germination } \\
\cline { 2 - 8 } $\mathrm{T}_{\mathrm{r}} \mathrm{4DAS}$ & $6 \mathrm{DAS}$ & $8 \mathrm{DAS}$ & $10 \mathrm{DAS}$ & $4 \mathrm{DAS}$ & $6 \mathrm{DAS}$ & $8 \mathrm{DAS}$ & $10 \mathrm{DAS}$ \\
\hline TOC & $58.33 \mathrm{a}$ & $86.67 \mathrm{a}$ & $96.67 \mathrm{a}$ & $100.00 \mathrm{a}$ & $50.00 \mathrm{a}$ & $83.33 \mathrm{a}$ & $100.00 \mathrm{a}$ & $100.00 \mathrm{a}$ \\
TNC & $5.00 \mathrm{~b}$ & $46.67 \mathrm{~b}$ & $61.67 \mathrm{~b}$ & $86.67 \mathrm{~b}$ & $3.33 \mathrm{a}$ & $40.00 \mathrm{~b}$ & $63.33 \mathrm{~b}$ & $76.67 \mathrm{~b}$ \\
TSC & $8.33 \mathrm{~b}$ & $46.67 \mathrm{~b}$ & $70.00 \mathrm{~b}$ & $83.30 \mathrm{~b}$ & $0.00 \mathrm{~b}$ & $46.67 \mathrm{~b}$ & $60.00 \mathrm{bc}$ & $76.67 \mathrm{~b}$ \\
TLC & $5.06 \mathrm{~b}$ & $53.33 \mathrm{~b}$ & $70.00 \mathrm{~b}$ & $90.00 \mathrm{~b}$ & $1.67 \mathrm{~b}$ & $40.00 \mathrm{~b}$ & $53.33 \mathrm{c}$ & $80.00 \mathrm{~b}$ \\
\hline
\end{tabular}

Note: Means followed by the same letters within the same column are not significantly different at $p \leq 0.05$, using DMRT. TOC $=$ Top soil from open space, $\mathrm{TNC}=$ Soil under Neem Tree, $\mathrm{TSC}=$ Soil under Shear butter Tree, TLC $=$ Soil under Locust Tree.

Table 2. Allelopathic effect of selected agroforestry trees on cowpea plant height at different growth stages.

\begin{tabular}{ccccccccccc}
\hline & \multicolumn{3}{c}{ POT Plant Height $(\mathrm{cm})$} & \multicolumn{5}{c}{ FIELD Plant Height $(\mathrm{cm})$} \\
\cline { 2 - 10 } Trt & 2 WAS & 4 WAS & 6 WAS & 8 WAS & 10 WAS & 2 WAS & 4 WAS & 6 WAS & 8 WAS & 10 WAS \\
\hline TOC & $10.00 \mathrm{a}$ & $19.00 \mathrm{a}$ & $34.73 \mathrm{a}$ & $36.97 \mathrm{a}$ & $38.00 \mathrm{a}$ & $10.13 \mathrm{a}$ & $16.77 \mathrm{a}$ & $28.40 \mathrm{a}$ & $32.13 \mathrm{a}$ & $35.03 \mathrm{a}$ \\
TNC & $7.70 \mathrm{~b}$ & $1083 \mathrm{~b}$ & $16.27 \mathrm{~b}$ & $19.83 \mathrm{~b}$ & $21.87 \mathrm{~b}$ & $8.23 \mathrm{~b}$ & $11.87 \mathrm{~b}$ & $15.83 \mathrm{~d}$ & $17.73 \mathrm{c}$ & $19.53 \mathrm{~b}$ \\
TSC & $6.90 \mathrm{c}$ & $11.70 \mathrm{~b}$ & $18.13 \mathrm{~b}$ & $21.93 \mathrm{~b}$ & $23.80 \mathrm{~b}$ & $6.83 \mathrm{c}$ & $11.23 \mathrm{c}$ & $19.13 \mathrm{~b}$ & $20.77 \mathrm{~b}$ & $23.53 \mathrm{~b}$ \\
TLC & $7.33 \mathrm{c}$ & $10.53 \mathrm{~b}$ & $17.23 \mathrm{~b}$ & $20.43 \mathrm{~b}$ & $22.87 \mathrm{~b}$ & $7.43 \mathrm{~b} \mathrm{c}$ & $10.30 \mathrm{c}$ & $16.90 \mathrm{c}$ & $18.20 \mathrm{c}$ & $20.10 \mathrm{c}$ \\
\hline
\end{tabular}

Note: Means followed by the same letters within the same column are not significantly different at $p<0.05$, using DMRT. TOC $=$ Top soil from open space, TNC = Soil under Neem Tree, TSC = Soil under Shear butter Tree, TLC = Soil under Locust Tree.

Table 3. Allelopathic effect of selected agroforestry trees on cowpea stem circumference at different growth stages.

\begin{tabular}{ccccccccccc}
\hline & \multicolumn{3}{c}{ POT Stem Circumference $(\mathrm{cm})$} & \multicolumn{5}{c}{ FIELD Stem Circumference (cm) } \\
\cline { 2 - 10 } $\mathrm{T}_{\mathrm{r}} \mathrm{n}$ & $2 \mathrm{WAS}$ & 4 WAS & 6 WAS & 8 WAS & 10 WAS & 2 WAS & 4 WAS & 6 WAS & 8 WAS & 10 WAS \\
\hline TOC & $0.53 \mathrm{a}$ & $0.97 \mathrm{a}$ & $2.17 \mathrm{a}$ & $2.60 \mathrm{a}$ & $2.93 \mathrm{a}$ & $0.50 \mathrm{a}$ & $0.83 \mathrm{a}$ & $1.93 \mathrm{a}$ & $2.07 \mathrm{a}$ & $2.27 \mathrm{a}$ \\
TNC & $0.43 \mathrm{~b}$ & $0.57 \mathrm{~b}$ & $0.63 \mathrm{~b}$ & $0.57 \mathrm{~b}$ & $1.15 \mathrm{~b}$ & $0.40 \mathrm{~b}$ & $0.57 \mathrm{~b}$ & $0.70 \mathrm{~b}$ & $0.83 \mathrm{~b}$ & $0.93 \mathrm{~b}$ \\
TSC & $0.40 \mathrm{~b}$ & $0.60 \mathrm{~b}$ & $0.70 \mathrm{~b}$ & $0.87 \mathrm{~b}$ & $1.33 \mathrm{~b}$ & $0.43 \mathrm{ab}$ & $0.57 \mathrm{~b}$ & $0.70 \mathrm{~b}$ & $0.83 \mathrm{~b}$ & $0.93 \mathrm{~b}$ \\
TLC & $0.47 \mathrm{ab}$ & $0.60 \mathrm{~b}$ & $0.70 \mathrm{~b}$ & $0.93 \mathrm{~b}$ & $1.10 \mathrm{~b}$ & $0.43 \mathrm{ab}$ & $0.57 \mathrm{~b}$ & $0.77 \mathrm{~b}$ & $0.77 \mathrm{~b}$ & $0.87 \mathrm{~b}$ \\
\hline
\end{tabular}

Note: Means followed by the same letters within the same column are not significantly different at $p<0.05$, using DMRT. TOC $=$ Top soil from open space, TNC = Soil under Neem Tree, TSC = Soil under Shear butter Tree, TLC = Soil under Locust Tree.

Table 4. Allelopathic effect of selected agroforestry trees on cowpea number of leaves at different growth stages.

\begin{tabular}{cccccccccccc}
\hline & \multicolumn{3}{c}{ POT number of leaves } & \multicolumn{5}{c}{ FIELD number of leaves } \\
\cline { 2 - 10 } $\mathrm{T}_{\mathrm{r}} \mathrm{c}$ & $2 \mathrm{WAS}$ & 4 WAS & 6 WAS & 8 WAS & 10 WAS & 2 WAS & 4 WAS & 6 WAS & 8 WAS & 10 WAS \\
\hline TOC & $7.00 \mathrm{a}$ & $16.67 \mathrm{a}$ & $31.67 \mathrm{a}$ & $35.33 \mathrm{a}$ & $41.00 \mathrm{a}$ & $7.33 \mathrm{a}$ & $17.67 \mathrm{a}$ & $27.33 \mathrm{a}$ & $28.33 \mathrm{a}$ & $37.00 \mathrm{a}$ \\
TNC & $8.00 \mathrm{a}$ & $11.33 \mathrm{~b}$ & $21.00 \mathrm{~b}$ & $24.33 \mathrm{~b}$ & $32.33 \mathrm{~b}$ & $6.33 \mathrm{a}$ & $11.33 \mathrm{c}$ & $20.33 \mathrm{c}$ & $22.33 \mathrm{bc}$ & $25.33 \mathrm{~b}$ \\
TSC & $7.33 \mathrm{a}$ & $13.00 \mathrm{~b}$ & $18.67 \mathrm{~b}$ & $23.33 \mathrm{~b}$ & $29.00 \mathrm{~b}$ & $7.00 \mathrm{ab}$ & $13.00 \mathrm{~b}$ & $19.00 \mathrm{c}$ & $20.67 \mathrm{c}$ & $25.00 \mathrm{~b}$ \\
TLC & $7.67 \mathrm{a}$ & $13.67 \mathrm{~b}$ & $22.00 \mathrm{~b}$ & $24.33 \mathrm{~b}$ & $28.00 \mathrm{~b}$ & $8.00 \mathrm{a}$ & $14.33 \mathrm{~b}$ & $22.67 \mathrm{~b}$ & $23.67 \mathrm{~b}$ & $28.33 \mathrm{~b}$ \\
\hline
\end{tabular}

Note: Means followed by the same letters within the same column are not significantly different at $p<0.05$, using DMRT. TOC $=$ Top soil from open space, TNC = Soil under Neem Tree, TSC = Soil under Shear butter Tree, TLC = Soil under Locust Tree. 
Table 5. Allelopathic effect of selected agroforestry trees on cowpea number of branches, root length and biomass yield at different growth stages.

\begin{tabular}{rcccccc}
\hline & \multicolumn{2}{c}{ No of Branches } & \multicolumn{2}{c}{ Root length $(\mathrm{cm})$} & Biomass yield $(\mathrm{g})$ & Biomass yield $(\mathrm{g})$ \\
\cline { 2 - 6 } $\mathrm{T}_{\mathrm{r}} \mathrm{r}$ & \multicolumn{5}{c}{ At Harvest } \\
\cline { 2 - 6 } & \multicolumn{1}{c}{ Pot } & Field & Pot & Field & Pot & Field \\
\hline TOC & $7.33 \mathrm{a}$ & $7.33 \mathrm{a}$ & $51.67 \mathrm{a}$ & $55.20 \mathrm{a}$ & $52.23 \mathrm{a}$ & $45.14 \mathrm{a}$ \\
TNC & $2.67 \mathrm{c}$ & $3.67 \mathrm{~b}$ & $40.00 \mathrm{~b}$ & $41.83 \mathrm{~b}$ & $28.80 \mathrm{~b}$ & $31.67 \mathrm{~b}$ \\
TSC & $3.67 \mathrm{bc}$ & $4.00 \mathrm{~b}$ & $44.03 \mathrm{ab}$ & $45.33 \mathrm{~b}$ & $32.17 \mathrm{~b}$ & $30.84 \mathrm{~b}$ \\
TLC & $4.67 \mathrm{~b}$ & $4.33 \mathrm{~b}$ & $45.20 \mathrm{ab}$ & $45.63 \mathrm{~b}$ & $32.44 \mathrm{~b}$ & $30.05 \mathrm{~b}$ \\
\hline
\end{tabular}

Note: Means followed by the same letters within the same column are not significantly different at $p<0.05$, using DMRT. TOC $=$ Top soil from open space, TNC $=$ Soil under Neem Tree, TSC $=$ Soil under Shear butter Tree, TLC $=$ Soil under Locust Tree.

\section{Conclusion}

In the tropics, tree stands on the farm or the cropping plots are a common occurrence for variety of reasons as have been listed earlier. However, this experiment had confirmed that Neem tree (Azardiracter indica), Locust tree (Parkia biglobosa), and shear butter tree (Vitellaria paradoxa) have inhibitory characteristics on both the germination and growth of cowpea. It is not unlikely that the tree species will have similar effects on other crops. Thus, in spite of other reasons for which trees are kept, farmers should also note these detrimental effects and therefore, if unavoidable ensure that the trees are widely spaced. Since the tree species understudied in this experiment are seldom grown by farmers (they are volunteers), it is advised that wherever they grow in clusters, the stands should be reduced if cropping will be carried out on such plots.

\section{References}

Ashrafi, Z., Mashhadi, H. R., \& Sadeghi, S. (2007). Allelopathic Effects of Barley (Hordeum vulgare) on Germination and Growth of Wild Varley (Hordeum spontaneum). Pakistan Journal of Weed Science Research, 13, 99-112.

Ashrafi, Z., Mashhadi, H. R., Sadeghi, S., \& Alizade, H. M. (2008). Effects Allelopathical of Sunflower (Helianthus annuus) on Germination and Growth of Wild Varley (Hordeum spontaneum). Journal of Agricultural Technology, 4, $219-229$.

Boffa, J. M. (1999). Agroforestry Parkland Systems in Sub-Saharan Africa: FAO Conservation Guide 34. Rome: Food and Agriculture Organization of the United Nations.

Bokhari, M. H., \& Aslam, K. M. (1985). Neem (Melia Azadirachta A. Juss). A Useful Tree in Northern Nigeria. Annals of Borno, II, 83-86.

Booth, F. E. M., \& Wickens, G. E. (1988). Non-Timber Uses of Selected Arid Zone Trees and Shrubs in Africa. FAO Conservation Guide 19. Rome: Food and Agriculture Organization of the United Nations, 103-109.

Davis, D. W., Oelke, E. A., Oplinger, E. S., Doll, J. D., Hanson, C. V., \& Putnam, D. H. (1991). Cowpea. Alternative Field Crops Manual. University of Wisconsin-Extension, Cooperative Extension University of Minnesota: Center for Alternative Plant and Animal Products and the Minnesota Extension Service.

Einhelling, F. A. (1996). Interactions Involving Allelopathy in Cropping Systems. Agronomy Journal, 88, 886-893. http://dx.doi.org/10.2134/agronj1996.00021962003600060007x

Gross, D., \& Paritheir, B. (1994). Novel Natural Substances Acting in Plant Growth Regulation. Journal of Plant Growth Regulation, 13, 93-114. http://dx.doi.org/10.1007/BF00210953

Hall, J., Aebischer, D., Tomlinson, H., Osei-Amaning, E., \& Hindle, J. (1996). Vitellaria Paradoxa: A Monograph. School of Agriculture and Forest Sciences Publication Number 8. Bangor, Wales: University of Wales.

Hopkins, H. C. (1983). The Taxonomy, Reproductive Biology and Economic Potential of Parkia (Leguminosae: Mimosoideae) in Africa and Madagascar. Botanical Journal of the Linnean Society, 87, 135-137.

http://dx.doi.org/10.1111/j.1095-8339.1983.tb00987.x

Inderjit, I. (1996). Plant Phenolies in Allelopathy. Botanical Review, 62, 186-202. http://dx.doi.org/10.1007/BF02857921

Inderjit, N., \& Dakshini, K. M. (1992). Formation 7-O Glucoside (Ononin), an Additional Growth Inhibitor in Soils Associated with the Weed, Pluchea Lanceolata (DC). Clarke (Asteraceae). Journal of Chemical Ecology, 18, 713-718.

http://dx.doi.org/10.1007/BF00994609

Kohli, R. K., Batish, D., \& Singh, H. P. (1998). Allelopathy and Its Implications in Agroecosystems. Journal of Crop Pro- 
duction, 1, 169-202. http://dx.doi.org/10.1300/J144v01n01_08

Maranz, S., Wiesman, Z., Bisgaard, J., \& Bianchi, G. (2004). Germplasm Resources of Vitellariaparadoxa Based on Variations in Fat Composition across the Species Distribution Range. Agroforestry Systems (in Cooperation with ICRAF), 60, 71. http://dx.doi.org/10.1023/B:AGFO.0000009406.19593.90

Mertz, O., Lykke, A. M., \& Reenberg, A. (2001). Importance and Seasonality of Vegetable Consumption and Marketing in Burkina Faso. Economic Botany, 55, 276-289. http://dx.doi.org/10.1007/BF02864565

Olaniyi, J. O. (2006). Influence of Nitrogen and Phosphorus Fertilizer on Seed Yield and Quality of Egusi Melon (Citrullus lanatus (Thunb) Mansf.) in Ogbomoso, Sourthwestern Nigiera. PhD Thesis, Ibadan: University of Ibadan, 199.

Putnam, A. R. (1985). Weed Allelopathy. In Duke, S. O. (Ed.), Weed Physiology. Reproduction and Ecophysiology (Volume 1, pp. 131-155). CRC Press.

Rice, L. E. (1984). Allelopathy. New York, London: Academic Press, 309-316.

Seligler, D. S. (1996). Chemistry and Mechanism of Allelopathic Interactions. Agronomy Journal, 88, 876-885. http://dx.doi.org/10.2134/agronj1996.00021962003600060006x

Shaukat, S. S., \& Siddiqui, I. A. (2001). Lantana Camara in the Soil Changes the Fungal Community Structure and Reduces Impact of Meloidogyne Javanica on Mungbean. Phytopathology Mediterranean, 40, 245-252.

Singh, B. B., Chambliss, O. L., \& Sharma, B. (1997). Recent Advances in Cowpea Breeding. 30-49 in Advances in Cowpea Research.

Von Maydell, H. (1990). Butyrospermum parkii (G. Don) Kotschy 202-207. Trees and Shrubs of the Sahel: Their Characteristics and Uses. English Text Revised J. Brase. Eschborn: Deutsche Gesellschaft fur Technische Zusammenarbeit (GTZ).

Von Maydell, H. J. (1986). Trees and Shrubs of the Sahel, Their Characteristics and Uses. Eschborn. 
Scientific Research Publishing (SCIRP) is one of the largest Open Access journal publishers. It is currently publishing more than 200 open access, online, peer-reviewed journals covering a wide range of academic disciplines. SCIRP serves the worldwide academic communities and contributes to the progress and application of science with its publication.

Other selected journals from SCIRP are listed as below. Submit your manuscript to us via either submit@scirp.org or Online Submission Portal.
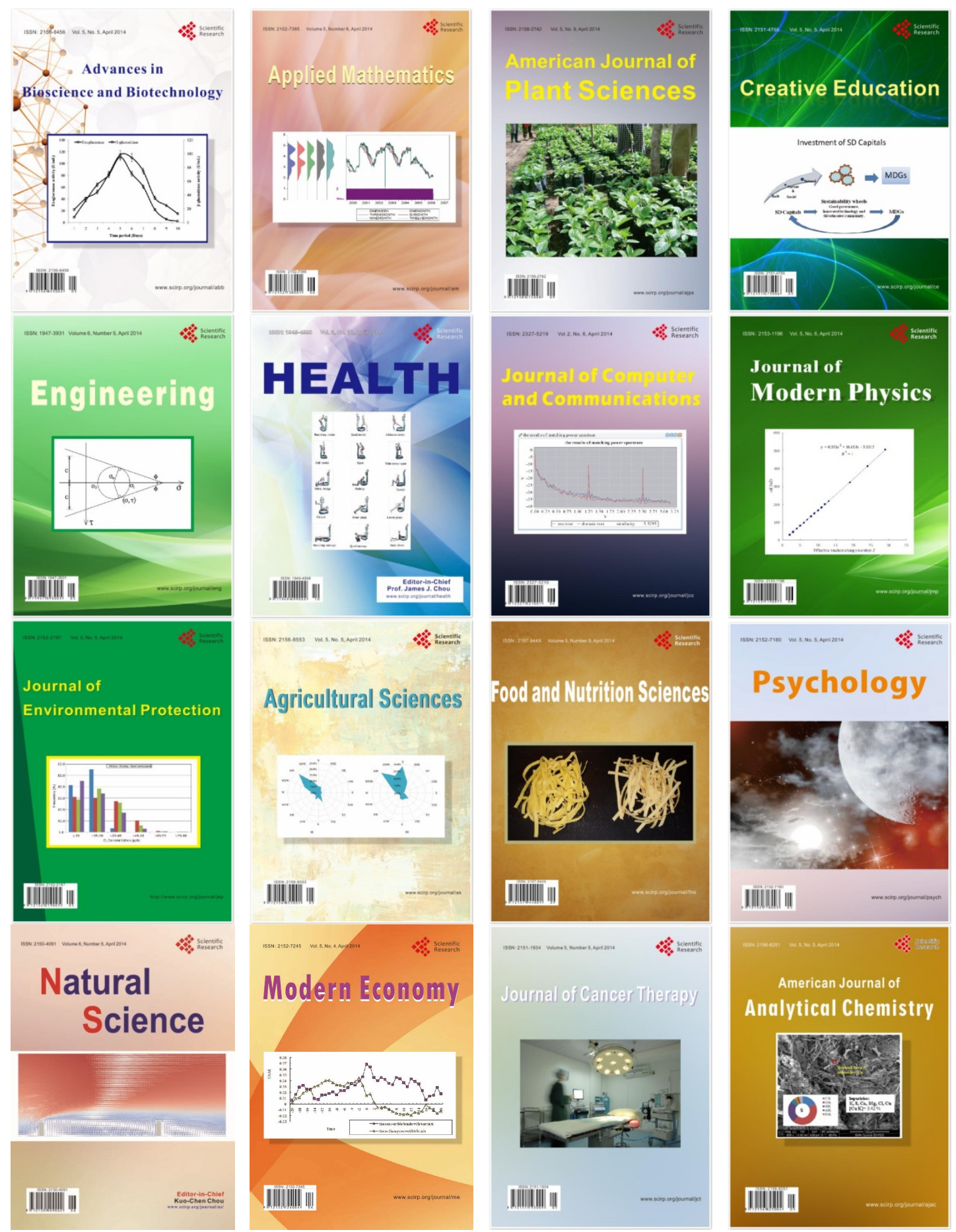